\title{
Rheological characteristics of alumina powders in dry pressing technology
}

JUDIT CsÁNYI - Department of Ceramics and Silicate Engineering, University of Miskolc csanyijudit@freemail.hu

\section{Aluminium-oxid porok reológiai tulajdonságainak változása sajtolás közben}

A cikk ismerteti a porlasztva szárított $\mathrm{Al}_{2} \mathrm{O}_{3}$ porok reológiai jellemzôit száraz porsajtolás esetén. A vizsgálatok kombinált reo-tribométerrel lettek végezve, melyet a Tanszék fejlesztett ki. A berendezés lehetôvé teszi a száraz, tömbszerú anyagok sajtolási folyamatának jellemzését mérhetố paraméterek által. Alkalmazva a berendezést, információt nyújt az alumínium-oxid porok viselkedésérôl sajtoláskor. A tanulmány ismerteti az egyes sajtolási fázisok reológiai modelljét. Tekintve a sajtolt $\mathrm{Al}_{2} \mathrm{O}_{3}$ por modelljét, az a szakirodalomból már ismert Gömze-féle reomechanikai egyenlettel leírható. Megállapítottá vált, hogy a magas $\mathrm{Al}_{2} \mathrm{O}_{3}$ tartalmú porok úgy viselkednek, mint a képlékeny-viszkoelasztikus anyagok, ahol a deformációk nagyon gyorsan végbemennek, így ezek a porok alkalmasak a dinamikus, gyors sajtolásra.

Kulcsszavak: $\mathrm{Al}_{2} \mathrm{O}_{3}$, reológia, reo-mechanikai modell, sajtolás

Keywords: $\mathrm{Al}_{2} \mathrm{O}_{3}$, rheology, rheo-mechanical modelling, pressing

\section{Introduction}

One of the most popular production method of alumina technical ceramics is the dry pressing. Stability, compactness and material structure of the ceramic products, produced by this technology are significantly influenced by the applied compaction method (single or double sided), by the pressing power, and by the geometry of the pressed product. The mechanical properties are especially influenced by the distribution of pressing power during compaction and by the reduction of its extent in the pressing powder $[1,2]$. Thus the optimum pressing conditions can only be determined knowing the rheological properties of the pressing powder [3].

During dry pressing spray-dried high purity $\mathrm{Al}_{2} \mathrm{O}_{3}$ granules are applied, including organic binding material with viscoelastic properties. Fig. 1. presents the dry powder pressing process. As a result of increasing pressing power the bulk density of the pressed specimen is continuously increasing, and after the termination of loading a so-called relaxation process begins, when the bulk density reduces $[4,5,6,7]$.

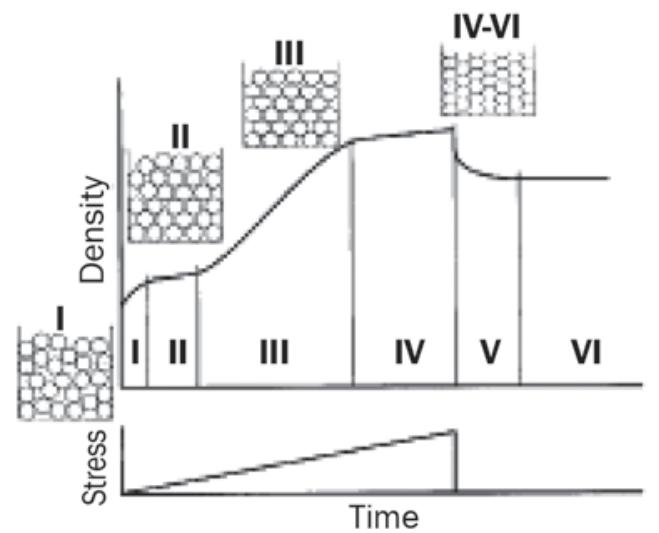

Fig. 1. Main phases of dry powder pressing (Taken from: R.D. Carneim, G.L. Messing: Powder Technology 115(2001)131-138[8])

1. ábra Száraz porsajtolás fóbb szakaszai
In theliterature several studies are dealing with the compaction and rheological properties of granules. Klausner et al used the annular shear cell [9] built by them for the investigation of rheological properties of cohesive powders. The research work of Carneim and Messing studied the impact of organic binding material and plasticizer in case of uniaxial pressing. In the study they describe and take into account the viscous-elastic properties of plasticizers. During the experiments, however no significant results were obtained for the joint impact of pressing powder and plasticizer [10]. Piccolroaz et al worked out another method, by which the deformation, resulting from mechanical power during pressing of granules, and the extent of cohesion between the granules can be defined and described. A plasticity-elastic mechanical model was used for the characterization of pressing [11].

Bruni, Lettieri, Newton and Barletta investigated the impact of grain size distribution on the yield and rheological behaviour of alumina powders. Peschl shear cell was used for discovering the rheological properties. It was found, that yield ability is basically influenced by grain size, and by the cohesion force between the granules [12].

The Department of Ceramics and Silicate Engineering has long traditions in the investigation of rheological properties of complex, non-linear, plastic-viscous elastic silicate industrial raw materials and semi-finished products, in the definition of their rheological models, in the mathematical analysis of stress conditions developed during the investigation. László A. Gömze et al investigated the crushing of pit-wet clay minerals, extrudability of cement asbestos, after pressing stress conditions of products, produced by extruder, and rheological properties of asphalt mixtures $[13,14,15,16]$.

The study presents the pressing and rheological properties of granules used by dry pressing. Furthermore, on the basis of the applied rheological tests and pressing experiments it presents rheological model and rheological material equation typical of the main steps of the pressing process!

\section{Materials and experimental procedure}

During the study the rheological properties of $96 \% \mathrm{Al}_{2} \mathrm{O}_{3}$ granules produced by Bakony Ipari Kerámia $\mathrm{Kft}$. were 
determined using the rheo-tribometre, developed by the Department of Ceramics and Silicate Engineering. The basic material of the pressing powder was ALO - GB 1 type alum earth, produced by MAL RT, which was further grinded and spray dried by the factory for us, adding different additives, like talc, calcite, bentonite and kaolin, as bulking materials. In case of the powders, produced by Bakony Ipari Kerámia Kft. it was possible to investigate other powders of same purity, but of different liter weight and of different grain-size distribution (Table 1.). Determination of grain-size distribution was made by Quantimet 570C image analyzing equipment. During the test the grainy areas were developed in several view fields, and the diameters were calculated from the obtained results. The analysis took into account the mean value of the grain diameters.

\begin{tabular}{lrrr} 
& $\mathbf{L - 2}$ & $\mathbf{L}-\mathbf{0}$ & $\mathbf{L}+\mathbf{2}$ \\
Granular size & \multicolumn{3}{c}{ Litre weight, $\mathbf{~ k g} / \mathbf{l}$} \\
& $\mathbf{1 , 2 0 8}$ & $\mathbf{1 , 2 3 1}$ & $\mathbf{1 , 2 5 1 8}$ \\
Average, $\mu \mathrm{m}$ & 86,300 & 74,000 & 97,400 \\
\hline Maximum, $\mu \mathrm{m}$ & 191,600 & 193,400 & 215,100 \\
\hline Minimum, $\mu \mathrm{m}$ & 17,000 & 16,400 & 17,200 \\
\hline Spread, $\mu \mathrm{m}$ & 34,300 & 37,500 & 49,700 \\
\hline Relative spread, \% & 39,700 & 50,700 & 51,000 \\
\hline
\end{tabular}

Table 1. Granular sizes of pressing powders

1. táblázat Sajtolóporok szemcseátmérö értéke

The combined rheo-tribometre instrument, shown on Fig. 2. was used for the determination of properties of dry powders, granules. The equipment (16) is installed on a table, to which the electromotor (9) is fixed with the cable drum (10) on its axle. The moving of the small car (15) is made by the endless ropeway (13) guided on rollers (17) and on the cable drum. The movement speed of the car can be adjusted continuously with the use of inverter speed regulator (11). The pneumatic cylinder (5) installed on the stand (14) produces the normal direction loading, the value of which can be adjusted by the pressure control valve (1), since the multiplication of the piston diameter and of the pressure inside the piston gives the value of $F_{n}$ indicated on Fig. 2. The pressure value can be seen on the pressure gauge (19). The specimen holding fixture (2) is fixed to the stand, where the material to be tested, in our case the alumina pressing powder can be placed. On the top part of the small car (15) the surface to be tested (4) can be placed, which can either be a plane surface (with variant surface quality) for measuring the external, dynamic friction coefficient, or a channelled one to investigate the internal friction of materials. The $\mathrm{F}_{\mathrm{t}}$ shearing force of the rope is measured by the load cell (8), car movement is measured by movement measurer (18), and the data supplied by these sensors are received by the data collecting unit (7), and is forwarded to the computer (6), where data processing takes place. The friction coefficient can be calculated as the ratio of the rope force and of the clamping force, produced by the pneumatic cylinder.

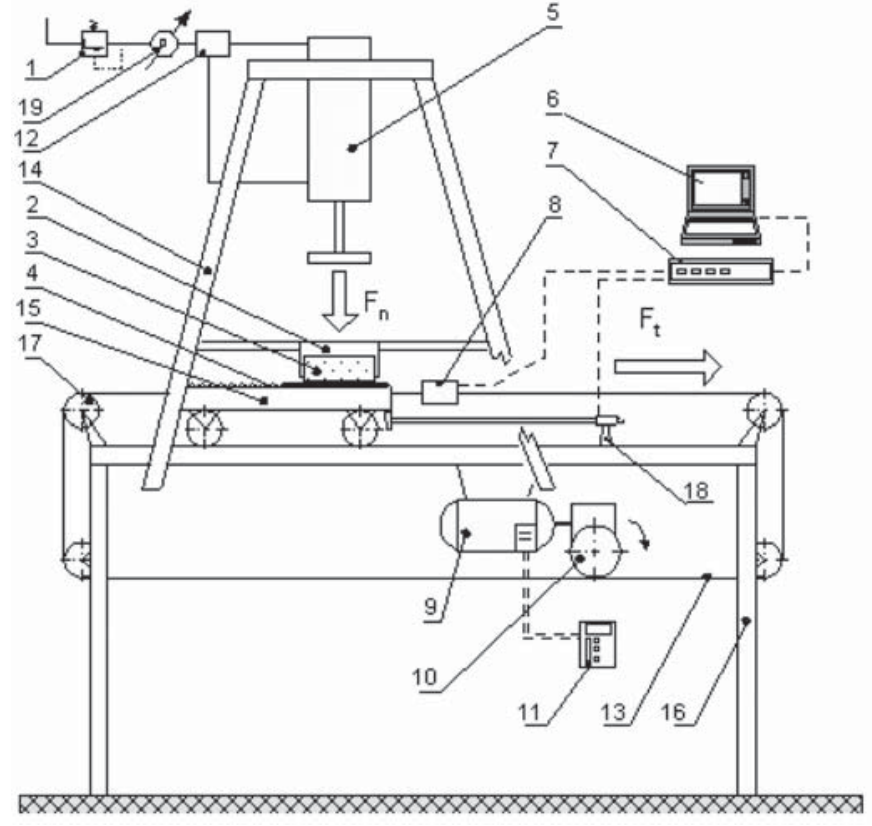

Fig. 2. Combined rheo- and tribometer [17]

2. ábra Kombinált reo-és tribométer

During each measurement series the same amount $(\mathrm{m}=$ $300 \mathrm{~g}$ ) of pressing powder is filled into the specimen fixture. Flat steel plate was used for the determination of external and internal friction coefficient. Pressing the filled volume with a constant $\mathrm{F}_{\mathrm{n}}$ force, and during this time releasing the connection between the cable drum (10) and the ropeway (13) the rheotribometre instrument was able to take the deformation-time curve, and then the system was loaded with a constant force.

The instrument, rebuilt according to the schematic drawing, illustrated on Fig. 3. was able to take the deformation-time curves of different grain size and grain structure alumina powders with varying $F_{n}$ pressure forces.

In bulk materials and grainy aggregations stress is developed as a result of external loadings and self-weight. Stress condition, developing at an optional point can be specified by Mohr's circle diagram. The boundary condition of grainy aggregates develops at a certain point, if the Mohr's diagram of the stress condition of the point reaches a certain boundary curve.

According to experiences the boundary curve can in many cases be well approximated by a linear, and can be described by the following equation

$$
\tau=\operatorname{tg} \Phi \cdot \sigma+c
$$

This boundary curve is otherwise called Coulomb linear, where $c$ is cohesion between the elements, $\Phi$ the internal friction angle, and $\operatorname{tg} \Phi$ is the internal friction coefficient. In case of materials, like dry sand - the cohesion of grainy material is zero, the boundary curve starts from the zero point.

On the basis of the results received the friction coefficient, the shearing tension could be calculated; thus the Coulomb linear can also be determined. 


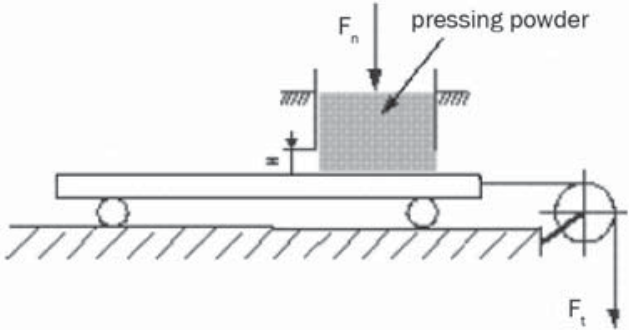

Fig. 3. Schematic drawing of rheological test performed on the rebuilt equipment 3. ábra Az átalakitott készüléken végzett reológiai vizsgálat elvi vázlata

\section{Results and discussion}

During the investigation of the impact of grain size distribution the pressing powder, prepared by Bakony Ipari Kerámia Kft. was used. Rheological properties of the pressing powder are influenced by the additive content, or by grain size distribution. In order to determine the additive content of pressing powder thermo analytical test was made, and it was found that there was no significant difference in the additive content of the pressing powders, used by us.

On the combined rheo-tribometre the shear force-time and displacement-time diagrams were taken with constant movement speed, pressing the filled volume with a constant $\mathrm{F}_{\mathrm{N}}$ force. The determination of maximum shear tension represents the Coulomb linear according to Fig. 4 . The equations of the linear taken were determined.

Equations of the different grain size distribution powders:

$$
\begin{array}{ll}
\text { Specimen } L-0: & \tau=0,1136 \sigma+0,004 \\
\text { Specimen } L-2: & \tau=0,1235 \sigma+0,0015 \\
\text { Specimen } \mathrm{L}+2: & \tau=0,1165 \sigma+0,0037
\end{array}
$$

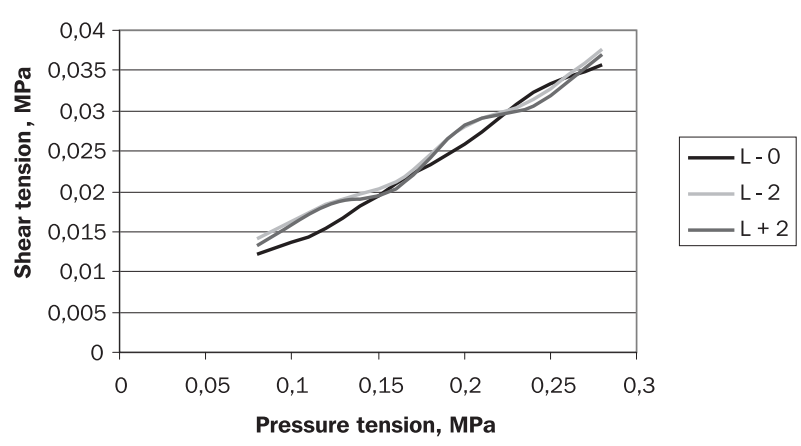

Fig. 4. Coulomb linear

4. ábra Coulomb-egyenes felvétele

During the rheological investigation the form of appearance of some pressing features can be observed. Reed distinguishes 3 main phases in the pressing process - the temporary rearrangement of granules, destruction, fragmentation of granules and the increase of volume density, taking into account the relation between pressing power and filling density. Pressing of cylindrical, disc shape alumina raw products can be described by density-pressing time diagram shown on Fig. 1., in the meantime increasing the pressing power linearly, in the function of the time. This curve was first described by Matsumoto et al [7].

Accordingly, in case of pressing power increasing linearly with time the process of density fluctuations can be divided into 6 main phases, where in the 1st phase the arrangement of the granules starts with the adding of pressing powder and the arrangement halts with the stopping of the force piston. In the 2nd phase forces, developed during the stopping of force piston affects the granules. In the 3rd phase the pressing process starts with the increase of power, the granules are deformed. In phase 4 the maximum compaction can be achieved by the deformation, fragmentation of granules. The 5 th phase begins with the driving out of the force piston, when the spring-back and relaxation process start. The product gets its final compactness and density in the final phase. During our studies slight compaction of the granules could be observed in the 1st phase, during which the granules were arranged sliding on each other and on the wall of the tool. The gaps between the granules were much bigger, than the average pores of the granule (Fig. 5.). In the 2nd phase the granules are deformed (Fig. 6.), fragmented as a result of the pressing power, and the volume of the relatively big gaps decreases. The compaction can be described by the following equation:

$$
D_{C}=D_{f}+m \ln \left(P_{a} / P_{y}\right)
$$

where $D_{C}$ - density of pressed product at $P_{a}$ - pressure; and $m$ - pressing constant, depending on the formability and on the size distribution of granules. Loading pressure of the granules containing additives $P y$, is less than $1 \mathrm{MPa} ; D_{f}$ is filling density.

The greater the additive and binding material content of the granules, the bigger pressure is needed to attain the uniform compactness. Phase 3 starts, when big pores disappear between the granules during deformation and as a result of the increased pressing power the shifted granules are rearranged or fragmented (Fig. 7.).

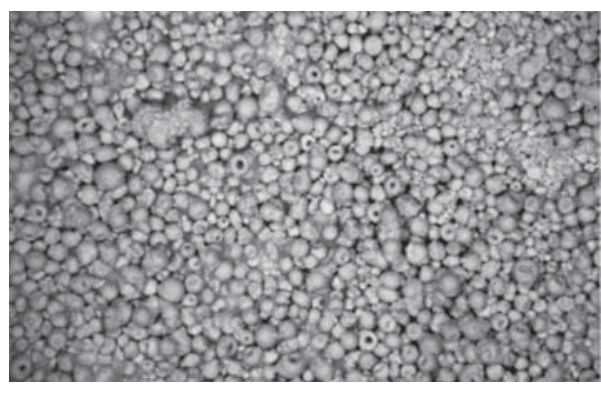

$N=20 X$

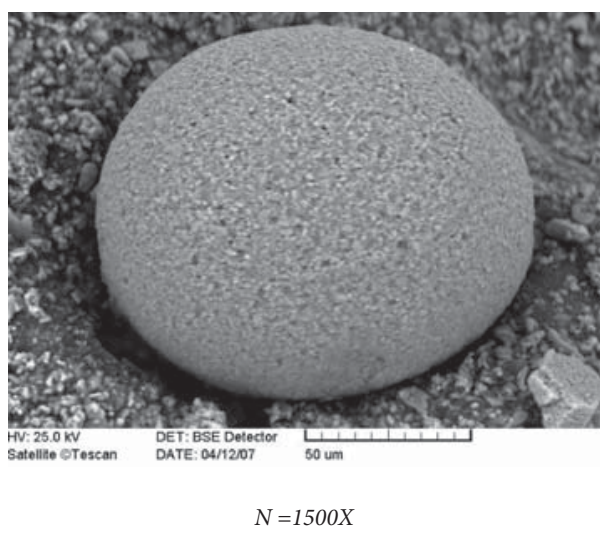

Fig. 5. 1st phase of pressing

5. ábra A sajtolás I. szakasza 


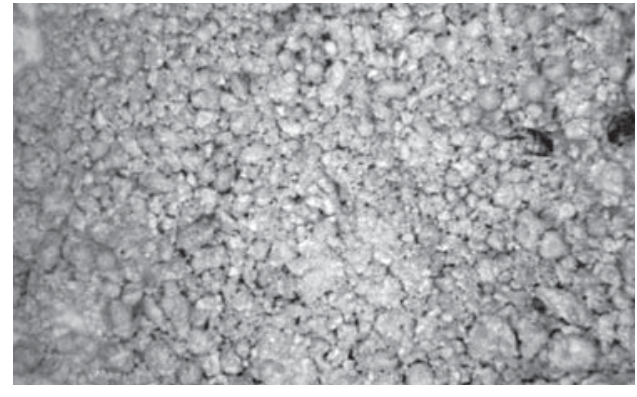

$N=8 X$

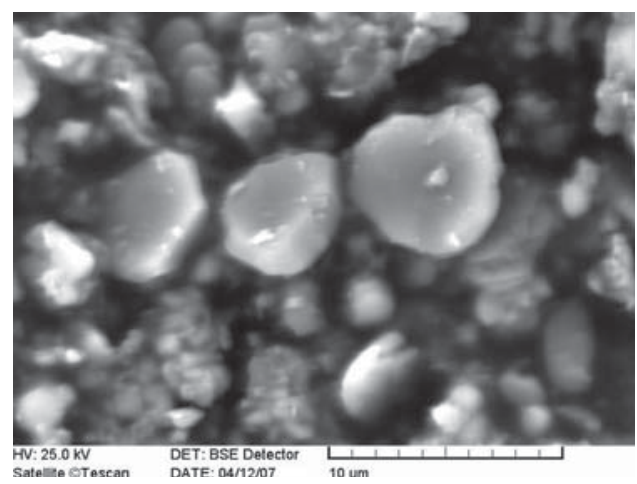

$N=10000 X$

Fig. 6. 2nd phase of pressing

6. ábra A sajtolás II. szakasza

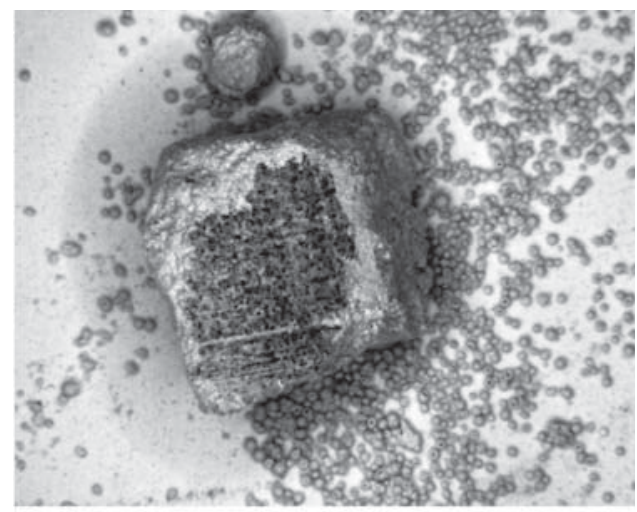

$N=8 X$

$N=8 X$

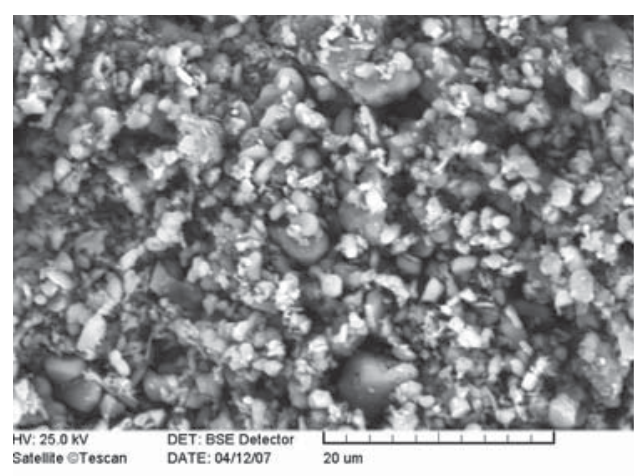

$N=5000 X$

$N=5000 X$

Fig. 7. 3rd phase of pressing

7. ábra A sajtolás III. szakasza
It can be concluded, that when using small pressing power $-0,08-0,28 \mathrm{MPa}-$ the powder is acting according to phases 1,2 and early 3 . The rheological model received by us can be described according to Fig. 8. a). Since the granules are already ordered, they will be deformed under further pressing power. Infinite time is needed to the rearrangement of the thus developed condition.

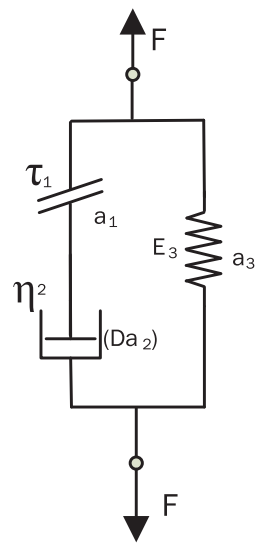

a) Behaviour of $\mathrm{Al}_{2} \mathrm{O}_{3}$ pressing powders in the 1st and 2 nd pressing phases

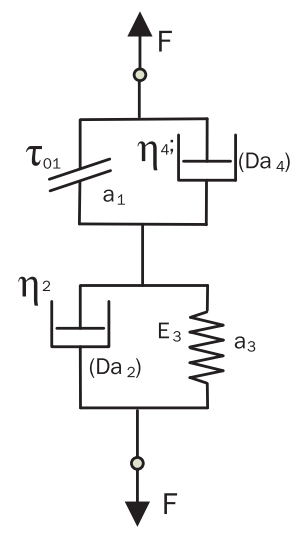

c) Grain destruction in phase 4

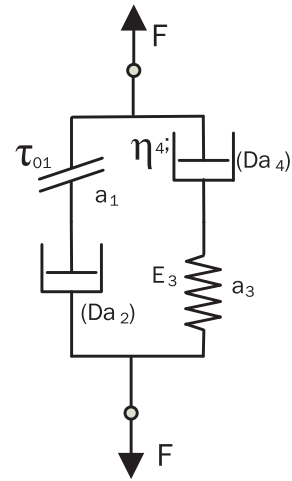

b) Adhesion of granules at the beginning of phase 3

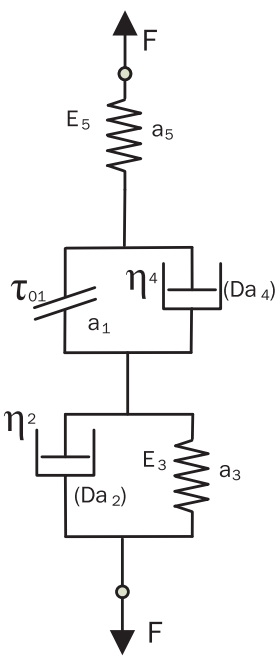

d) Spring-back and relaxation in phases 5-6

Fig. 8. Rheological models of alumina powders in main pressing phases

8. ábra Alumínium-oxid sajtolóporok reológiai modelljei a sajtolás fó szakaszaiban

As a result of pressing power the wetting materials (additives) on the surface of pressing powders contribute to the sliding of granules on each other and on the wall of the tool, as well as to the adhesion of the granules. From the point of view of their rheological behaviour the additives can be described by viscous or by viscoelastic model [8]. The model can be described according to Fig. 8. b).

During grain destruction the investigated system divides into two parts, which can be seen in the rheological model, too (Fig. 8. c). 
The spring-back after the termination of the loading is well-known in case powder-like, ceramic materials. After the termination of pressing part of the tension developed in the system returns to the system, the granules spring back, increasing by this the product volume and the density of pressed products. The spring-back effect is provided by a flexible member, series connected to our model (Fig. 8. d). Rheological model of $\mathrm{Al}_{2} \mathrm{O}_{3}$ pressing powder actually corresponds to the already known rheological model of asbestos cement. Fig. 9. shows the characteristic curve of the described model. It can be seen, that this model is identical not only with the rheological model of alumina powders, but also of other, powder like materials. The identity of the two models (Fig. 8. d and 9.) means that Gömze's material and rheological equations can also be written for alumina powders [18].

Gömze’s rheo-mechanical equation:

$$
\tau=\tau_{0}+\eta_{1} \cdot \dot{a}+\eta_{1} \cdot \ddot{a} \cdot t_{a}-\left[t_{\tau}-t_{a} \cdot\left(1+\frac{\eta_{2}}{\eta_{1}}\right)\right] \cdot \dot{\tau}-t_{\tau} \cdot t_{a} \cdot \ddot{\tau}
$$

The deformation is described by Gömze's deformation function:

$$
a_{t}=C \cdot\left(\frac{1}{E_{1}}+\frac{1}{\eta_{1}}\right) \cdot H(t)+\tau_{0}+\frac{C}{E_{2}}\left[1-\exp \left(-\frac{E_{2}}{\eta_{2}} t\right)\right] \cdot H(t)
$$
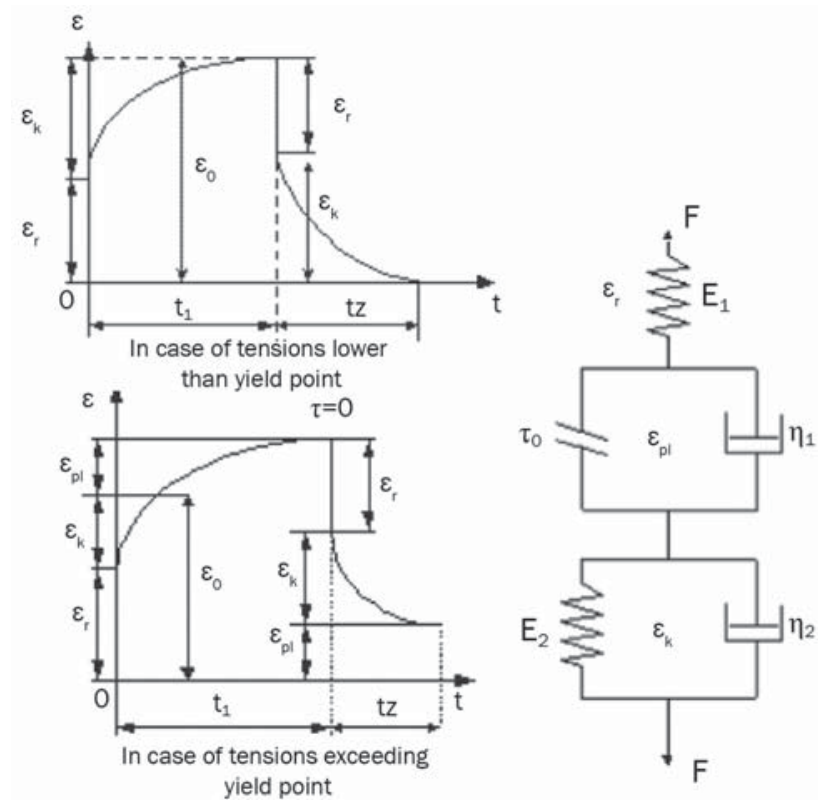

$E_{1}$ - Hookean dynamic modulus

$\tau_{0}$ - Static yield point of the visco-plastic body

$\eta_{1}$ - Viscosity of the plastic-viscose body

$E_{2}$ - Dynamic modulus of Voigt-Kelvin test

$\eta_{2}-$ Viscosity of Voigt-Kelvin test

$\varepsilon$ - Actual elastic deformation

$\varepsilon_{p 1}$ - Plasticity-viscous deformation

$\varepsilon_{k}$ - Delayed elastic deformation
Fig. 9. Typical deformation-time function and rheological model of asbestos-cement (Taken from: László A Gömze: Vibor osnovnih parametrov shnekovih pressov dlia formovaniya ctroitel'nih izdelij iz asbestotzementnih mass, Avtoreferat, Moscow, 1985. UDK 666961033022

9. ábra Azbesztcement tipikus deformáció-idő függvénye és reológiai modellje

\section{Conclusions}

As a result of tests, performed with combined reo-tribometre it was possible to determine the external friction coefficient of different composition alumina atomizer powders on steel surface, as well as the range of their internal friction coefficient in the function of pressure power, sliding or deformation speed,
Építőanyag, vol. XXXV, N.5; (1983) pp.173-176

[14] Gömze A. László: Some Problems of Dimensioning the Smooth Rolls Used for Crushing Clay Minerals; Építőanyag, vol. XXXII., N.11. (1980) pp. 428 432

[15] Gömze A. László: Some up to day Questions of bTheory of Crushing Crushing of Clay Minerals on Pan-Mills; Épitőanyag, vol. LV, N.3, (2003) pp. 133-140.

[16] Gömze A. László, Kovács Ákos: Investigation of Rheological Properties of Asphalt Mixtures; Építőanyag; vol. 57; N.2, (2005) pp. 34-37

[17] Gömze, A.L, Kocserha, I., Czél, Gy.: Kombined Rheo- and Treibometer Equipment Hungarian Patent, Lajstromszám:2434, U0200079 (2002)

[18] Gömze A. László.: Vibor osnovnih parametrov shnekovih pressov dlia formovaniya ctroitel'nih izdelij iz asbestotzementnih mass, Avtoreferat, Moscow, 1985. UDK 666961033022 